УДК 7.079:792 73

DOI https://doi.org/10.31723/2524-0447-2021-32-1-28

\author{
Зоряна Петрівна Рось \\ ORCID: 0000-0002-5962-2790 \\ кандидат мистецтвознавства, \\ доцент кафедри виконавського мистеитва \\ Навчально-наукового інституту мистеитв \\ Прикарпатського національного університету імені Василя Стефаника \\ zorianaros@gmail.com \\ Ірина Олександрівна Полякова \\ ORCID: 0000-0002-8119-9335 \\ кандидат педагогічних наук, доцент, \\ завідувач кафедри естрадно-вокального мистецтва \\ Університету Короля Данила \\ poliakovairyna749@gmail.com

\section{ВПЛИВ ЕСТРАДНО-ВОКАЛЬНОЇ ТВОРЧОСТІ М. СКОРИКА НА РОЗВИТОК УКРАЇНСЬКОГО ЕСТРАДНОГО ВОКАЛЬНОГО МИСТЕЦТВА}

\begin{abstract}
Мета роботи - окреслити сфери впливу естрадно-вокальних творів Мирослава Скорика на розвиток вокально-естрадного мистецтва в Україні та визначити їх роль у формуванні української пісенної естради. Методологія дослідження визначається комплексним підходом до вибору методів. Так, історичний, культурно-мистеиький, інтегративний методи передбачали осмислення значення творчого доробку М. Скорика для розвитку сучасної української пісенної естради; теоретичні методи (аналітичний, синтезування, абстрагування, узагальнення інформації) дали змогу виявити й систематизувати інтонаційно-ритмічні, жанрово-стилістичні й композиційні особливості естрадно-пісенної творчості М. Скорика; емпіричний метод (спостереження) дав змогу окреслити особливості вокальних композицій мития і визначити їх місце в сучасному українському естрадному мистецтві. Наукова новизна. Усвідомлено значення творчого доробку М. Скорика для розвитку сучасної української пісенної естради; розкрито й систематизовано інтонаційно-ритмічні, жсанрово-стилістичні й композиційні особливості естрадно-пісенної творчості М. Скорика; визначено напрями їх впливу на розвиток сучасної української естрадної пісні. Композитор започаткував новий напрям естрадно-пісенної творчості, де поєднав українські інтонації з ритмами джазу, танго, блюзу, халі-галі, твісту, босанови
\end{abstract}

(C) Рось 3. П., Полякова I. О., 2021 
та ін., що панували тоді у світі, але були маловідомі в Україні. Висновки. Охарактеризовано стилістичні особливості вокально-естрадних композицій М. Скорика та визначено їх місие в сучасному українському естрадному мистецтві. Композитор поєднує риси естрадно-джазовоі пісні 60-х років XX століття (рок-н-ролу, регтайму, блюзу та ін.) 3 прийомами академічної музики (складною гармонією, тембровим мисленням, різними ускладненнями куплетної форми, інструментальним трактуванням ансамблю (хору), трансформацією академічної форми рондо тощо). Таким чином, синтез академічного й естрадного визначив основні тенденції стильового розвитку вокально-естрадного жканру як професійного мистецтва, що стало запорукою високих художніх результатів.

Ключові слова: естрадно-вокальне мистецтво, прийоми академічної музики, вокально-естрадні жанри.

Ros' Zoryana Petrivna, Doctor of Philosophy in Art Studies, Associate Professor at the Department of Performing Arts of the Educational and Scientific Institute of Arts of Vasyl Stefanyk Precarpathian National University

Polyakova Iryna Oleksandrivna, Candidate of Pedagogical Sciences, Associate Professor, Head of the Department of Pop and Vocal Arts of the King Danylo University

\section{The influence of pop-vocal creativity of Skoryk development of Ukrainian pop-vocal arts}

The purpose of the work - to outline the spheres of influence of pop vocal works of Myroslav Skoryk on the development of vocal pop art in Ukraine and to determine their role in the formation of Ukrainian song pop. The research methodology is based on a comprehensive approach to the choice of methods, in particular, historical, cultural and artistic, integrative methods provided for understanding the significance of M. Skoryk's creative work for the development of modern Ukrainian song pop; theoretical methods - analytical, synthesis, abstraction, generalization of information made it possible to identify and systematize intonation-rhythmic, genre-stylistic and compositional features of pop-song creativity of M. Skoryk; empirical method - observation made it possible to outline the features of the artist's vocal compositions and determine their place in contemporary Ukrainian pop art. Scientific novelty - the significance of M. Skoryk's creative work for the development of modern Ukrainian song variety is realized and the intonation-rhythmic, genre-stylistic and compositional features of M. Skoryk's pop-song creativity are revealed and systematized, the directions of their influence on the development of modern Ukrainian pop song are determined. The composer started a new direction of pop and song creativity, where he combined Ukrainian intonations with the rhythms of jazz, tango, blues, halihali, twist, bosanova, etc., which prevailed in the world at that time, but were little known in Ukraine. Conclusions. The stylistic features of M. Skoryk's vocal and pop compositions are characterized and their place in modern Ukrainian pop art is determined. The composer combines the features of pop-jazz song of the 60s of the XX century (rock ' $n$ ' roll, ragtime, blues, etc.) 
with the techniques of academic music - complex harmony, timbre thinking, various complications of the couplet form, instrumental interpretation of the ensemble (choir), transformation of the academic form of the rondo. Thus, the synthesis of academic and pop identified the main trends in the stylistic development of the vocal and pop genre as a professional art that has become a guarantee of high artistic results.

Key words: pop-vocal art, techniques of academic music, vocal pop genres.

Актуальність теми дослідження. Мирослав Скорик - видатний український композитор і музикознавець, Герой України, народний артист України, лауреат премії імені Т.Г. Шевченка, кандидат мистецтвознавства, співголова Спілки композиторів України 2006-2010 років, художній керівник Київської опери (2011-2016), у творчому доробку якого є вагомі загальновідомі класичні твори. Але свій творчий шлях митець почав із захоплення у 60-ті рр. жанрами естрадної музики, створивши низку пісень, які вплинули на розвиток вокально-естрадного мистецтва в Україні й формування української пісенної естради.

Питанням розвитку української музики, зокрема естрадного мистецтва, присвячено праці таких вітчизняних дослідників, як І. Антонюк, А. Коннікова, Т. Самої, В. Тормахової, Л. Черкашиної та ін. Розвиток української естради другої половини XX століття знайшов своє відображення в наукових розвідках М. Барановської, О. Грачової, Ю. Драбчук та ін., а також безпосередньо в дисертаційному дослідженні М. Мозгового на тему «Тенденції становлення й розвитку української естрадної пісні». Аналізу творчого шляху М. Скорика присвячені роботи К. Борисенка, М. Гереги, Т. Гнатів, О. Голинської, М. Гордійчука, М. Загайкевич, Л. Кияновської, Т. Ланіної, М. Маслій, І. Мринської, О. Найдюк, Л. Олійник, В. Романка, І. Сікорської, П. Турянського, Ю. Щериці, Я. Якуб'яка та ін.

Незважаючи на високу художню цінність і популярність цих творів, на великий масив інформації про особистість та творчість Мирослава Скорика в міжнародній мережі Internet, пресі та медіапросторі, естрадно-вокальна творчість композитора поки що не стала предметом окремого наукового дослідження і дотепер не отримала належної уваги наукової думки, що і визначило тему цієї статті.

Мета дослідження - окреслити сфери впливу естрадновокальних творів Мирослава Скорика на розвиток вокально- 
естрадного мистецтва в Україні та визначити їх роль у формуванні української пісенної естради.

Наукова новизна. У своїх естрадних творах композитор започаткував новий напрям української естрадної пісні, де поєднав українські інтонації з ритмами джазу, танго, блюзу, халі-галі, твісту, босанови та ін., що панували тоді у світі, але були маловідомі в Україні. На основі систематизації інтонаційно-ритмічних, жанрово-стилістичних і композиційних особливостей естрадно-пісенної творчості М. Скорика визначено напрями їх впливу на розвиток сучасної української пісенної естради.

Виклад основного матеріалу. У другій половині XX і початку XXI століть українська естрада пройшла декілька етапів свого розвитку.

Естрадна пісня 1950-1960 років - це період формування української естрадної пісні як жанру. Він позначений розвитком на той час нової національної музики в радянських республіках, яка була наповнена сподіваннями, романтизмом та свободою. В образно-емоційному складі естрадної пісні вагомого значення набувають пейзажні мотиви (оспівування неосяжних ланів, річок, гірських круч, квітучого саду тощо). Саме тоді в Україні розквітає творчість відомих українських композиторів О. Білаша, В. Верменича, Г. Майбороди, П. Майбороди, С. Сабадаша, І. Шамо, М. Скорика, які писали вокальні твори на вірші класиків української поезії XX століття. Їх пісні характеризувалися мелодійністю, ліричністю, фольклорною стилістикою та національним характером. Спостерігається збільшення інтересу українських композиторів до гуцульського фольклору з притаманними йому яскравою інтонаційною характерністю й багатим місцевим колоритом. До цього періоду належать і твори розважальної естрадно-танцювальної музики. Так, великою популярністю серед естрадних пісень користувалися твори М. Скорика «Карпати» (вірші М. Петренка), «Не топчіть конвалій» (вірші Р. Братуня), «Львівський вечір» і «Принесіть мені маків» (вірші Б. Стельмаха) та ін., у яких трансформовано ритмо-гармонічні елементи популярних танців (рок-н-ролу, твісту, шейку, босанови тощо).

Як зазначає Ю. Драбчук, у цей період «посилюється академізація пісенного виконавства. Професійна сфера здійснює все вагоміший вплив на музикантів: поширюються масштабні 
форми, зростають вимоги до художніх творів, удосконалюється музичне інструментування» [2]. Розвиток цих нових тенденцій і якостей можна спостерігати у вокально-естрадній творчості Мирослава Скорика.

Естрадна пісня періоду 1970-х - першої половини 1980-х років - це етап розквіту української естрадної пісні. М. Мозговий відзначає у своєму дисертаційному дослідженні, що «цей період характеризується появою професійних та аматорських вокально-інструментальних ансамблів, особливе місце серед яких посідає ВIА «Смерічка» та творчість В. Івасюка, завдяки яким українська естрадна пісня виходить за межі української радянської республіки» [6]. У цей час існували також такі колективи, як «Мрія», «Червона рута», «Кобза», «Ватра», «Водограй» та ін. На естраді з'являються професійні джазові оркестри, які виконували інструментальні композиції, попурі на мотиви українських народних пісень та шлягерів української естради. Також розвивається авторська пісня. Саме тоді на українській естраді з'являється новий напрям - бардівська пісня.

Друга половина 1980-2000 pp. - це етап трансформації української естради на засадах розвитку шоу-бізнесу. З'являються нові естрадні гурти («Гроно», «ВВ», «Океан Ельзи» та ін.); продюсерські центри, які займаються підготовкою та організацією різних мистецьких акцій, підготовкою шоу-програм тощо; активізується розвиток фестивального руху. Так, М. Скорик підтримував і брав активну участь у розвитку фестивального руху в Україні: був одним з організаторів міжнародного музичного фестивалю «Контрасти», який щороку проходить у Львові; разом зі своїм учнем І. Карабіцем започаткував (а 32002 р. був художнім керівником) фестиваль «Київ-Музик-Фест»; у 2005 р. був головою журі фестивалю «Червона рута» тощо.

Естрадно-вокальне мистецтво як соціальний феномен i музичне явище починає привертати увагу науковців, серед яких Н. Сапожник, Л. Тормахова, Н. Попович, М. Мозговий, Л. Васильєва, А. Бондаренко та ін., які у своїх дослідженнях порушують питання стилістики, напрямів та жанрових різновидів української пісенної естради.

На думку М. Мозгового, «у сучасному культурно-мистецькому просторі України кінця XX - початку XXI ст. простежуються процеси стильового розмаїття у розвитку естрадно-во- 
кального мистецтва... Естрадно-вокальна музика в Україні представлена широким спектром стилів, напрямів, жанрів, які пов'язані між собою. Деякі з'явилися в результаті синтезу двох і більше з них. Вона розвивається у вигляді трьох основних складників, як-от рок-, джаз- та поп-музика, які представлені на українській естраді» [6].

Серед представників старшого покоління українських композиторів, які стояли у витоків формування жанру української естрадної пісні, відоме ім'я Мирослава Скорика.

Його родина була тісно пов'язана з українськими мистецькими, науковими, суспільно-просвітницькими колами Галичини, відіграла значну роль у суспільно-культурному житті краю. «Ця органічна єдність національного і загальноєвропейського, самобутньо-фольклорного і конструктивного, породженого художніми пошуками 50-60-х років XX ст. відобразилась в естетичному світогляді Мирослава Скорика через півстоліття як природне продовження і розвиток його родової традиції, як свідчення його справжньої «генетичної» інтелігентності, забезпечивши колосальний трамплін для злету його індивідуальності» [3]. Композитор прожив довге і достойне життя, тому, починаючи від знакових 1960-х років, ось уже півстоліття українська музична культура пов'язана з іменем Мирослава Скорика.

М. Скорик як композитор створив багато музичних шедеврів, які відомі як в Україні, так і за кордоном. У його композиторській творчій спадщині є твори різних жанрів: опера «Мойсей»; 2 балети («Каменярі» за I. Франком, «Повернення Баттерфляй» Скорик-Пуччіні); музична комедія «0:0 на нашу користь», 5 великих вокально-симфонічних творів (кантати); 8 симфонічних композицій (симфонічна поеми, сюїти, концерти тощо); 4 твори для камерного оркестру; 4 концерти для інструментів соло 3 оркестром; 7 камерно-інструментальних творів; низка творів для фортепіано; вокальні твори: романси на слова Т. Шевченка, 3 псалми, Духовний концерт «Реквієм», Літургія святого Йоана Золотоустого; музика до 12 фільмів; численні естрадні пісні; низка теоретичних праць.

Особливе місце у творчому доробку маестро посідав джаз, яким він почав захоплюватися ще в молоді роки. «Власне, його шлях розпочався із написання популярних джазово-естрадних творів: ритм-н-блюзового «Львівського вечора», «Намалюй мені Ніч» в жанрі бугі-вугі, блюзових «Аеліти», «Карпат», 
«Я тебе почекаю, коханий», регтаймової «Принесіть мені маків» та першого українського твісту «Не топчіть конвалій». Тому закономірно, що Мирослав Михайлович є палким знавцем джазу, грає сам і пише в цьому стилі [1]. Першим виконавцем його естрадних творів був створений ним у Львові вокально-інструментальний ансамбль «Веселі скрипки». Як представник «нової фольклорної хвилі» М. Скорик органічно використовує художні елементи джазової художньої культури, зберігаючи при цьому самобутність і національні риси української пісенності. «3 його іменем на українську естрадну сцену увірвалися авангардні для неї ритми і жанри, що панували тоді у світі... Виявилося, що українська поезія, галицька пісня-романс і гуцульський фольклор чудово співіснують із ритмами американського рок-н-ролу, халі-галі, танго, босанови!» [5, с. 12]. Із самого початку діяльність композитора в цьому напрямі відзначалася спрямованістю на професійний рівень. Як зазначає О. Голинська, «Скорик віртуозно об'єднує класичні традиції з джазовими ритмами, європейські джазові традиції з власною композиторською мовою, індивідуальними тембровими прийомами, щоби музику зрозуміли різні люди» [1].

Він зумів зламав кригу, як зазначає Л. Кияновська, однобокої тенденції офіціозно-помпезних масових пісень «про комсомол і партію», що на той час заполонили радіоефір і концерти легкої музики, «переступив» і через традиції української лірично-сентиментальної пісні, що панувала ще у творчості авторів старшого покоління, та вніс в демократичне масове пісенне мистецтво гострі ритми рок-н-ролу, свободу джазової гармонії і ритміки, не втративши своєрідності гуцульського фольклору та західноукраїнських пісень-романсів. [3, с. 345]. Отже, його шлях розпочався із написання популярних джазово-естрадних творів. Проект «Золотий фонд української естради» презентує найповнішу натепер добірку пісень геніального Мирослава Скорика (19 творів), як-от:

«Аеліта» (сл. Б. Стельмаха)

«Вечори на Високому замку» (сл. Р. Братуня)

«Жоржини» (сл. О. Вратарьова)

«Карпати» (сл. М. Петренка)

«Квіти говорять» (сл. М. Сома)

«Кінчалась ніч» (авт. сл. уточнюється)

«Львівський вечір» (сл. Б. Стельмаха) 
«Намалюй мені ніч» (сл. М. Петренка)

«Не знаю» (сл. М. Скорика)

«Не топчіть конвалій» (сл. Р. Братуня)

«Нічне місто» (сл. М. Петренка)

«Свіча» (сл. Б. Стельмаха)

«Твої рушники» (сл. І. Бердника)

«Ти забудь ці слова» (сл. М. Петренка)

«Три трембіти» (сл. О. Вратарьова)

«Фата Моргана» (сл. І. Лазаревського)

«Я жду тебе - Коли любить» (авт.сл. уточнюється)

«Я не сумую за тобою» (сл. О. Вратарьова)

«Я тебе почекаю» (сл. Б. Стельмаха)

Сам композитор зазначав: «Щодо естради, то я взагалі не вважаю це другорядною сферою своєї творчості, навіть зробив нещодавно нові аранжування своїх пісень. Я не знаю, в якому я форматі. Загалом, не розумію, що таке формат і що таке неформат на нинішніх радіостанціях. Музика, мистецтво або є, або нема»[4].

У результаті аналізу найбільш відомих естрадних вокальних композицій М. Скорика, що в 60-х рр. ламали офіційні штампи радянських масових пісень, варто вказати на такі особливості.

Мирослав Скорик у своїх естрадно-вокальних композиціях послідовно звертається до жанрових і стильових особливостей джазу та латиноамериканських танців: рок-н-ролу («Аеліта», «Львівський вечір»), блюзу («Аеліта», «Карпати», «Я тебе почекаю, коханий»), регтайму («Аеліта», «Принесіть мені маків»), ритм-н-блюзу («Львівський вечір»), бугі-вугі («Львівський вечір», «Карпати», «Нічне місто», «Принесіть мені маків», «Намалюй мені ніч»), свінгу («Львівський вечір», «Принесіть мені маків», «Намалюй мені ніч»), фанку («Карпати»), бігвини («Карпати», «Я тебе почекаю, коханий»), соулу («Я тебе почекаю, коханий»), твісту («Не топчіть конвалій») та ін.

У своїх естрадних піснях композитор звертається до куплетної форми, яка є традиційною для жанру популярної пісні («Я тебе почекаю, коханий», «Львівський вечір», «Нічне місто», «Не топчіть конвалій»), але в деяких творах трактує iii оригінально, зокрема у розміщенні тематичного матеріалу зверненням до принципів формоутворення рондо. Таким чином, виникає оригінальне трактування куплетної форми, де приспів немов обрамлений повторенням заспіву («Нічне 
місто») або поверненням до початкового варіанта приспіву («Я тебе почекаю»). Ознаки рондо спостерігаються і в пісні «Не топчіть конвалій», яка починається 3 приспіву, який відграє роль рефрену, що надає цілісності всій композиції. А пісня «Аеліта» становить традиційну форму рондо (рефрен «То не комета, то не сузір'я»).

У заспівах дуже часто використовує чергування розсnівних $\boldsymbol{i}$ мовних варіантів одного й того ж мелодичного мотиву («Нічне місто»). Мелодії приспівів у М. Скорика характеризуються широкими інтервальними кроками: початок - енергійний стрибок вгору, від якого шляхом оспівування теми мелодія рухається у низхідному напрямку («Нічне місто», «Я тебе почекаю»). Водночас у подальшому розвитку (і в словах, і у вокальній партіi) відбувається активізація темпоритму за рахунок більш динамічного розгортання мелодики і ритмізованого акомпанементу. Однак проблема головної кульмінації (динамічної, фактурної, теситурної) вирішується так, що вона припадає на перші два рядки приспіву, тому завершення куплета відзначене згасанням і тенденцією до затихання.

Звернення до жанрових і стильових особливостей джазу та латиноамериканських танців зумовили різноманітність рumмічної структури творів, а саме: метричне зміщення однієї й тієї ж ритмічної формули («Нічне місто»), використання синкоп («Аеліта», «Львівський вечір»), зміщення акцентів із першої долі на другу або третю в чотиридольному метрі («Я тебе почекаю»); акцентування слабких долей такту 3 використанням пунктирного розгойдування (свінгу) середніх голосів фактури («Нічне місто») тощо.

Ладо-гармонічна мова в кожному творі є індивідуалізованою і залежить від характеру музичного образу. Так, наприклад, у пісні «Нічне місто» вона є гострою, хроматизованою, з малосекундовими поступовими підйомами і спадами, а голосоведення наповнене паралелізмами інтервалів і акордів. У пісні «Аеліта» М. Скорик мислить септакордовими гармоніями: ні тоніка, ні інші акорди мажоро-мінорної системи не представлені у вигляді тризвуків, найчастіше - у вигляді септакордів та їх обернень або акордів із побічними неакордовими тонами. У пісні «Львівський вечір» акордика простіша, ніж в «Аеліті»: використовуються тризвуки, секстакорди, квартсекстакорди, застосовується багато паралелізмів, поєднання натуральних акордів сусідніх ступенів тощо. «Намалюй мені 
ніч» - це постійне використання альтерації, а також септакордів та їх обернень, що становлять основні види акордики твору. Гармонічні засоби «Карпат» - септакордові побудови, альтерації й побічні неакордові звуки тощо.

Композитор часто сполучає або чергує сольне виконання 3 ансамблевим (хоровим) звучанням («Аеліта», «Не топчіть конвалій», «Львівський вечір» та ін.). Таке фактурне зіставлення породжує тембровий контраст і звучить несподівано й цікаво. В пісні «Аеліта» тема рефрену («То не комета, то не сузір'я») будується як діалог між солістом і хором (ансамблем). Щодо цього можна зауважити, що притаманна темі діалогова манера (структура питання-відповідь) властива блюзовим пісням.

Усі естрадні пісні М. Скорика виконуються в супроводі інструментального ансамблю або фортепіано і майже всі починаються 3 інструментального вступу (окрім пісні «Не топчіть конвалій», яка відразу починається з вокалу). Фактура інструментального супроводу багата і різноманітна. Наприклад, партія фортепіано в пісні «Намалюй мені ніч» звучить як імпровізація, в якій яскраво представлено свінгові розкачування пунктирних ритмічних зворотів у поєднанні зі синкопами у високому регістрі на тлі гострого тритонового співвідношення октав у басах і мелодизованого плавного середнього шару фактури. Разом із вокалом і появою в партії фортепіано типової ритмічної формули бугі-вугі утворюється поліритмічне звучання. Гостроту цій темі надає також наявність і багатократне підкреслення тритону у верхньому голосі фактури. Мелодія фортепіано складає немов другий голос, що відтіняє своїм мелодичним малюнком вокальну партію.

Висновки. «Він не вдавався до стилізації чи популізму, зазначає композитор О. Щетинський, - а писав сучасною музичною мовою і не цурався показувати тонкий інтелект і винахідливість. У них я чую буяння творчого начала, нестандартний виразний тематизм, стислість і продуманість розвитку, ретельно пророблену фактуру, цікаві розв'язання в оркеструванні» [8].

Мирослав Скорик у своїх вокально-естрадних композиціях поєднує риси естрадно-джазової пісні $60-\mathrm{X}$ років XX століття (рок-н-ролу, регтайму, блюзу та ін.) з прийомами академічної музики: складною гармонією, тембровим мисленням, різними ускладненнями куплетної форми, інструментальним трактуванням ансамблю (хору), трансформацією академічної 
форми рондо. Останнє виявляться у тому, як видозмінюється рефрен, як взаємодіють між собою (за принципом контрасту) епізоди тощо. Це говорить про вдалий синтез серйозного (академічного) і легкого (естрадного) жанрів, в чому й виявляються основні тенденції стильового розвитку цього жанру як професійного мистецтва і що стало запорукою високих художніх результатів.

\section{СПИСОК ЛІТЕРАТУРИ}

1. Голинська О. Мирослав Скорик у стилі Jazz. Український інтернет-жмрнал «Музика». Київ. 25 травня 2018.

2. Драбчук Ю.П. Українська пісенна естрада 50-80-х років. URL: https://revolution.allbest.ru/music/00606482_0.html

3. Кияновська Л.О. Мирослав Скорик: людина і митець. Львів : СПОЛОМ, 2008. $591 \mathrm{c}$.

4. Кияновська Л.О. Мирослав Скорик: людина i митець ДІАЛОГИ Інтерв'ю $з$ композитором. 23 вересня 2013, URL: http://www.m-r.co.ua/mr/mr.nsf/0/5352A53CA9 2339D5C 15.

5. Мозговий М. П Тенденції становлення розвитку української естрадної пісні : автореф. дис. ... канд. мист. : спец. 17.00.01 «Теорія та історія культури»; Київський національний університет культури і мистецтв. Київ, 2007. 24 с.

6. Олійник Л. Мирослав Скорик: «Моя професія - створювати мелодії. URL: https://day.kyiv.ua/uk/article/kultura/miroslav-skorikmoya-profesiya-stvoryu vati-melodiyi

7. Романко В. Творчість Мирослава Скорика і джаз. Науковий вісник Національної музичної академії України ім. П.І. Чайковського. Мирослав Скорик. Вип. 10. Київ : НМАУ, 2000. С. 48-53.

8. Stas Nevmerzhytskyi. Контекст і підтекст музики Мирослава Скорика. URL: https://theclaquers.com/posts/3722

\section{REFERENCES}

1. Holyns'ka O. (2018). Myroslav Skoryk u styli Jazz. Ukrayins'kyy internet-zhurnal «Muzyka». Kyyiv. 25 travnya [in Ukrainian].

2. Drabchuk YU. P. Ukrayins'ka pisenna estrada 50-80-kh rokiv. URL: https://revolution.allbest.ru/music/00606482_0.html [in Ukrainian].

3. Kyyanovs'ka L. O. (2008). Myroslav Skoryk: lyudyna i mytets' [Myroslav Skoryk: man and artist ]. L'viv : SPOLOM. [in Ukrainian].

4. Kyyanovs'ka L. O. (2013). Myroslav Skoryk: lyudyna i mytets'. L'viv : SPOLOM. [in Ukrainian].

5. Mozhovyy M. P (2007). Tendentsiyi stanovlennya rozvytku ukrayins'koyi estradnoyi pisni: Exlendetd abstract of candidate's thesis. Kyiv National University of Culture and Art. Ktyyiv. [in Ukrainian].

6. Oliynyk L. Myroslav Skoryk: «Moya profesiya - stvoryuvaty melodiyi». URL: https://day.kyiv.ua/uk/article/kultura/miroslav-skorikmoya- 
7. Romanko V. (2000). Tvorchist' Myroslava Skoryka i dzhaz. Naukovyy visnyk Natsional'noyi muzychnoyi akademiyi Ukrayiny im. P. I. Chaykovs'koho. Myroslav Skoryk. Vyp. 10. Kyyiv: NMAU. [in Ukrainian].

8. Stas Nevmerzhytskyi. Kontekst i pidtekst muzyky Myroslava Skoryka. URL: https://theclaquers.com/posts/3722 